\title{
Geoscięnces
}

\section{Geochemical fingerprint of siliceous, amphibolitic and magnetitic itabirite types of the region of Serra Azul - Quadrilátero Ferrífero, MG}

http://dx.doi.org/10.1590/0370-44672015680104

\author{
Ana Ramalho Alkmim \\ Mestre pelo PPGECRN/DEGEO/UFOP \\ Universidade Federal de Ouro Preto, \\ Escola de Minas, Departamento de Geologia \\ Ouro Preto - Minas Gerais - Brazil \\ ana_alkmim@yahoo.com.br
}

\section{Geraldo Magela Santos Sampaio Doutorando pelo PPGECRN/DEGEO/UFOP Universidade Federal de Ouro Preto, \\ Escola de Minas, Departamento de Geologia Ouro Preto - Minas Gerais - Brazil geraldomssampaio@gmail.com}

\section{Júlia Cotta Maciel Dantas}

Graduanda em Engenharia Geológica pela UFOP Universidade Federal de Ouro Preto,

Escola de Minas, Departamento de Geologia Ouro Preto - Minas Gerais - Brazil

juliacmd@yahoo.com.br

\section{Adriana Trópia de Abreu \\ Doutora - Técnica do Laboratório de Geoquímica do DEGEO/UFOP \\ Universidade Federal de Ouro Preto, \\ Escola de Minas, Departamento de Geologia \\ Ouro Preto - Minas Gerais - Brazil \\ adrianatropia@gmail.com}

\section{Caracterização geoquímica dos itabiritos silicoso, anfibolítico e magnetítico da região de Serra Azul - QF, MG}

\begin{abstract}
Banded iron formations are important providers of information about the evolution of the hydrosphere, atmosphere, biosphere and lithosphere of the Earth. This study gathers data from the geochemical investigation of major, minor and trace elements (including rare earth elements) of the siliceous, amphibolitic and magnetitic types of itabirite from the Cauê Formation, sampled in the Serra Azul region (Quadrilátero Ferrífero).

Observing the trace elements described as tracers of detrital contamination can be inferred that the magnetitic itabirite has the highest contamination and that the siliceous type has the lowest one.

Although there are differences in the total sum of REE in the three itabirite types of Serra Azul, there are no discrepancies in the REE spectrum of each type. The itabirite types have as common characteristics in their REE spectrum: i) positive Eu anomalies (Planavsky et al., 2010); ii) HREE enrichment in relation to the LREE; iii) ratios of $(\mathrm{Sm} / \mathrm{Yb})_{\mathrm{SN}}<1$ and $(\mathrm{Eu} / \mathrm{Sm})_{\mathrm{SN}}>1$ (Bau \& Möller, 1993). The magnetitic and the siliceous itabirites had positive $\mathrm{Y}$ anomalies, a common characteristic that appeared in some amphibolitic samples. On the other hand, the other amphibolitic samples had negative $\mathrm{Y}$ anomalies.
\end{abstract}

Keywords: Cauê Formation, Itabirite, geochemistry, REE, BIF.

\section{Resumo}

Formações ferriferas são importantes fontes de informações sobre a evolução da hidrosfera, atmosfera, biosfera e litosfera da Terra. Esse trabalho reúne dados geoquimicos de elementos maiores, menores e traços (incluindo os elementos terras raras) dos itabiritos silicoso, anfibolítico e magnetítico da Formação Canê provenientes da região de Serra Azul (QF).

Em se tratando das concentrações de elementos-traço, considerados traçadores de contaminação detrital, pode-se inferir que o tipo magnetítico é o que possui uma maior contaminação e que o silicoso, a menor.

Embora existam diferenças no somatório total de ETR nos três diferentes tipos de itabiritos estudados, na região de Serra Azul, não foi possivel verificar discrepâncias muito significativas no espectro de ETR dos três diferentes tipos estudados. São características comuns aos três tipos de itabiritos: i) anomalias positivas de Eu (Pla- 
navsky et al., 2010); ii) enriquecimento em ETR pesados em relação aos leves; iii) razões $(\mathrm{Sm} / \mathrm{Yb})_{S N}<1$ e $(\mathrm{Eu} / \mathrm{Sm})_{S N}>1$ (Bau \& Möller, 1993). Os itabiritos magnetítico e o silicoso possuem ainda em comum anomalias positivas de Y, uma característica que aparece em algumas amostras do tipo anfibolitico também. As outras amostras de itabirito anfibolitico possuem anomalias negativas de $Y$.

Palavra-chave: Formação Cauê, itabiritos, geoquímica, FFB, ETR.

\section{Introduction}

The mineral province of Quadrilátero Ferrífero $(\mathrm{QF})$ is known by its gold deposits and high world quality iron ores deposits. It is located in the southeastern border of the São Francisco Craton, a block relatively stable of Archean and Paleoproterozoic rocks surrounded by Neoproterozoic orogenic belts (Almeida, 1977; Alkmim \& Marshak, 1998).

Besides its economic importance, banded iron formations are important providers of data about the evolution of the hydrosphere, atmosphere, biosphere and lithosphere of the Earth (e.g. Dis-

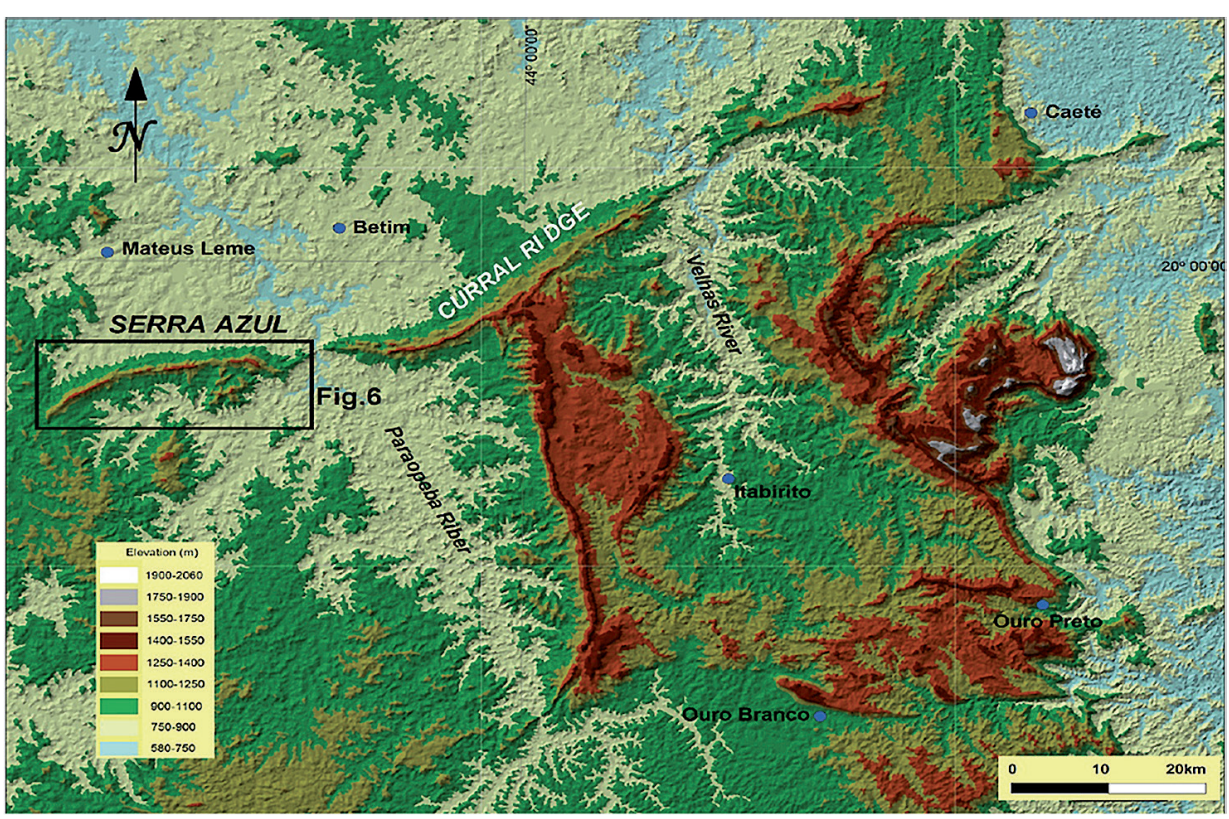

mukes et al., 2001; Liang et al., 2006; Pufahl, 2010).

The Cauê Iron Formation hosts the iron deposits of the QF province and has apparently the same age as other Paleoproterozoic iron formations around the world. The main lithotype of the Cauê Formation is the Itabirite (metamorphic banded iron formation), and in the QF, there can be distinguished five types: siliceous, amphibolitic, magnetitic, dolomitic and manganesiferous (Pires, 1995; Rosière \& Chemale Jr., 2000; Amorim \& Alkmim, 2011).

Known as the Serra Azul region
(Figure 1), the western segment of the Curral Ridge is a region that experienced low deformation and metamorphism (Pires, 1995; Amorim \& Alkmim, 2011). Because of this, the geochemical composition of the itabirites of this region approaches the composition of the original sedimentary protoliths of the Cauê Formation.

This study gathers data of major, minor and trace elements (including rare earth elements-REE) of the siliceous, amphibolitic and magnetitic types of itabirite from the Cauê Formation sampled in the Serra Azul region (QF).

Figure 1

Digital topographic model of the QF region locating the Serra Azul in Amorim e Alkmim (2011)

\section{Materials and methods}

For this study, samples of the siliceous, amphibolitic and magnetitic types of the Cauê Itabirites collected at USIMINAS Mineração were selected. These samples were crushed, homogenized, pulverized and dried for one hour at a temperature of $100^{\circ} \mathrm{C}$.

Major and minor elements were determined through inductively coupled plasma optical emission spectrometry (ICP-OES) and the total iron and ferrous iron content was determined through the titulometric method. The results were validated using the certificated reference material IPT-21A and the quality control material proposed by Sampaio (2012), duplicated samples and blank solutions.

Trace elements, including REE (Rare Earth Elements), were determined by inductively coupled plasma mass spectrometry (ICP-MS). The lanthanides and Yttrium will be called REE herein and were analyzed after acidic dissolution using PFA Savillex ${ }^{\circledR}$ tubes described by Sampaio (2012). The reference material used for the quality control of this method was GIT-IWG (France). In addition, duplicated sample dissolution and blank solutions were performed.

As suggested by Bolhar et al. (2004) and Spier et al. (2007), the results of the REE concentrations were normalized by PAAS (Post Archean Australian Shale - SN) (McLennan, 1989). 


\section{Results}

Geochemically, the magnetitic itabirite has low concentrations of $\mathrm{SiO}_{2}$ $(38.67 \%), \mathrm{P}_{2} \mathrm{O}_{5}(0.06 \%)$ and $\mathrm{Fe}_{2} \mathrm{O}_{3}$ $(23.86 \%)$, if compared with the other types of itabirites from Serra Azul.

With high concentrations of the oxides: $\mathrm{Mn}(0.37 \%)$, Ca (4.20\%), $\mathrm{Ti}(0.004 \%), \mathrm{Mg}(4.96 \%)$ and Fe II $(13.95 \%)$, these green rocks are rich in the trace elements, such as: $\mathrm{Cr}(4.765$ $\mu \mathrm{g} / \mathrm{g})$, Cs $(0.905 \mu \mathrm{g} / \mathrm{g})$, Sc $(0.158 \mu \mathrm{g} / \mathrm{g})$, $\mathrm{Ga}(0.253 \mu \mathrm{g} / \mathrm{g}), \mathrm{Rb}(1.242 \mu \mathrm{g} / \mathrm{g}), \mathrm{Sr}$ $(15.238 \mu \mathrm{g} / \mathrm{g}), \mathrm{Zr}(1.110 \mu \mathrm{g} / \mathrm{g}), \mathrm{Hf}(0.024$

Figure 2

REE spectrum of the magnetitic itabirite from Serra Azul, PASS normalized (McLennan, 1989).

The siliceous itabirite possesses a medium composition of $\mathrm{SiO}_{2}(43.76 \%)$, $\mathrm{Fe}_{2} \mathrm{O}_{3}(50.54 \%)$, and $\mathrm{FeO}(1.94 \%)$, with low contents of $\mathrm{Al}_{2} \mathrm{O}_{3}(0.034 \%), \mathrm{MnO}$ $(0.100 \%)$, and $\mathrm{TiO}_{2}(0.001 \%)$ when compared with the other two types of itabirite studied. Rich in trace elements, such as $\mathrm{Nb}(0.093 \mu \mathrm{g} / \mathrm{g})$, In (0.007 $\mu \mathrm{g} / \mathrm{g})$ and $\mathrm{Sn}(0.207 \mu \mathrm{g} / \mathrm{g})$, the siliceous itabirite have low concentrations of $\mathrm{Ni}$ (2.737 $\mu \mathrm{g} / \mathrm{g}), \mathrm{Ga}(0.172 \mu \mathrm{g} / \mathrm{g}), \mathrm{Rb}(0.172$ $\mu \mathrm{g} / \mathrm{g}), \operatorname{Sr}(0.973 \mu \mathrm{g} / \mathrm{g}), \mathrm{Zr}(0.686 \mu \mathrm{g} / \mathrm{g})$

Figure 3

REE spectrum of the siliceous itabirite from Serra Azul, PASS normalized (McLennan, 1989). $\mu \mathrm{g} / \mathrm{g})$, Th $(0.222 \mu \mathrm{g} / \mathrm{g})$ and $\mathrm{Bi}(0.021$ $\mu \mathrm{g} / \mathrm{g})$ and have low concentrations of $\mathrm{Ni}(4.126 \mu \mathrm{g} / \mathrm{g}), \mathrm{Cu}(2.902 \mu \mathrm{g} / \mathrm{g}), \mathrm{Nb}$ $(0.054 \mu \mathrm{g} / \mathrm{g})$, In $(0.0049 \mu \mathrm{g} / \mathrm{g})$ and $\mathrm{Ba}$ (15.273 $\mu \mathrm{g} / \mathrm{g})$.

Containing a total concentration of REE between $5.466 \mu \mathrm{g} / \mathrm{g}$ and 42.663 $\mu \mathrm{g} / \mathrm{g}$, the magnetitic itabirite has in general an REE spectrum (Figure 2) characterized by the presence of positive anomalies of Eu (Planavsky, 2010) and $\mathrm{Y}$, negative anomalies of $\mathrm{Ce}$ (Bau \& Dulski, 1996), enrichment in HREE (heavy REE) in relation to the LREE (light REE) and Y/Ho ratios near 38.67. Studying the criteria suggested by Bau \& Möller (1993) for iron formations, the magnetitic itabirite shows ratios of $(\mathrm{Sm} / \mathrm{Yb})_{S \mathrm{~N}}<1$ and $(\mathrm{Eu} / \mathrm{Sm})_{\mathrm{SN}}>1$. Deeply studying the $\mathrm{Ce}$ anomalies as suggested by Planavsky (2010) and Bau \& Dulski (1996), the proposed ratios $\left(\mathrm{Ce} / \mathrm{Ce}^{*}\right)$ ${ }_{S N}$ e $\left(\operatorname{Pr} / \mathrm{Pr}^{*}\right)_{S N}$ were respectively less or near one, leading to indicate that the $\mathrm{Ce}$ negative anomalies were in fact positive anomalies of $\mathrm{La}$ in the samples.

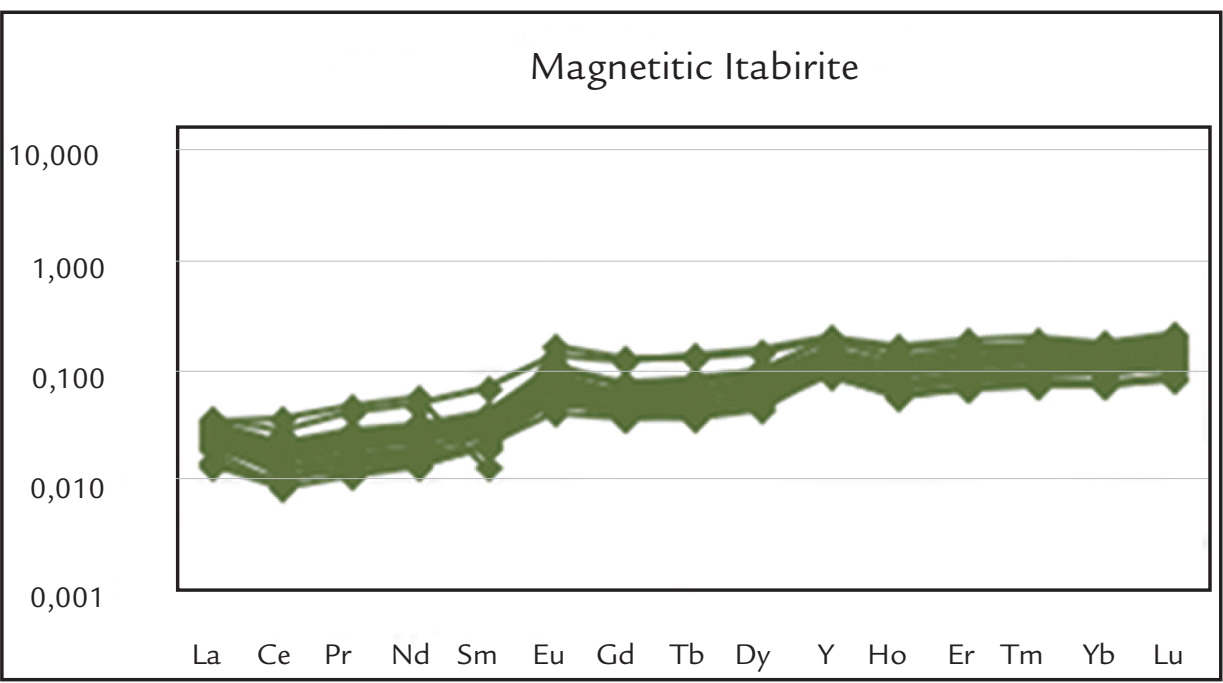

Cs $(0.033 \mu \mathrm{g} / \mathrm{g}), \mathrm{Ba}(10.567 \mu \mathrm{g} / \mathrm{g}), \mathrm{Hf}$ $(0.012 \mu \mathrm{g} / \mathrm{g})$ and $\mathrm{U}(0.099 \mu \mathrm{g} / \mathrm{g})$.

Studying the contents of REE, the general sum of concentration of the siliceous itabirite remains between $4.410 \mu \mathrm{g} / \mathrm{g}$ and $12.519 \mu \mathrm{g} / \mathrm{g}$. The general REE spectrum of this type of rock (Figure 3) presents positive anomalies of Eu (Planavsky, 2010) and Y, negative anomalies of Ce (Bau \& Dulski, 1996), enrichment in HREE in relation to LREE and Y/Ho ratios near 35.59.
Analyzing the Bau \& Möller (1993) criteria, the siliceous itabirite has ratios of $(\mathrm{Sm} / \mathrm{Yb})_{\mathrm{SN}}<1$ and $(\mathrm{Eu} / \mathrm{Sm})_{\mathrm{SN}}>1$. Wanting to verify the veracity of the $\mathrm{Ce}$ anomalies, the ratios $\left(\mathrm{Ce} / \mathrm{Ce}^{*}\right)_{\mathrm{SN}}<1$ and $(\mathrm{Pr} / \mathrm{Pr} *)_{\mathrm{SN}} \approx 1$ (Planavsky, 2010; Bau \& Dulski, 1996), were observed and possibly indicate that the Ce negative anomalies were generated in some samples from anomalous La concentration used in the math calculation. Only five samples had true negative Ce anomalies.

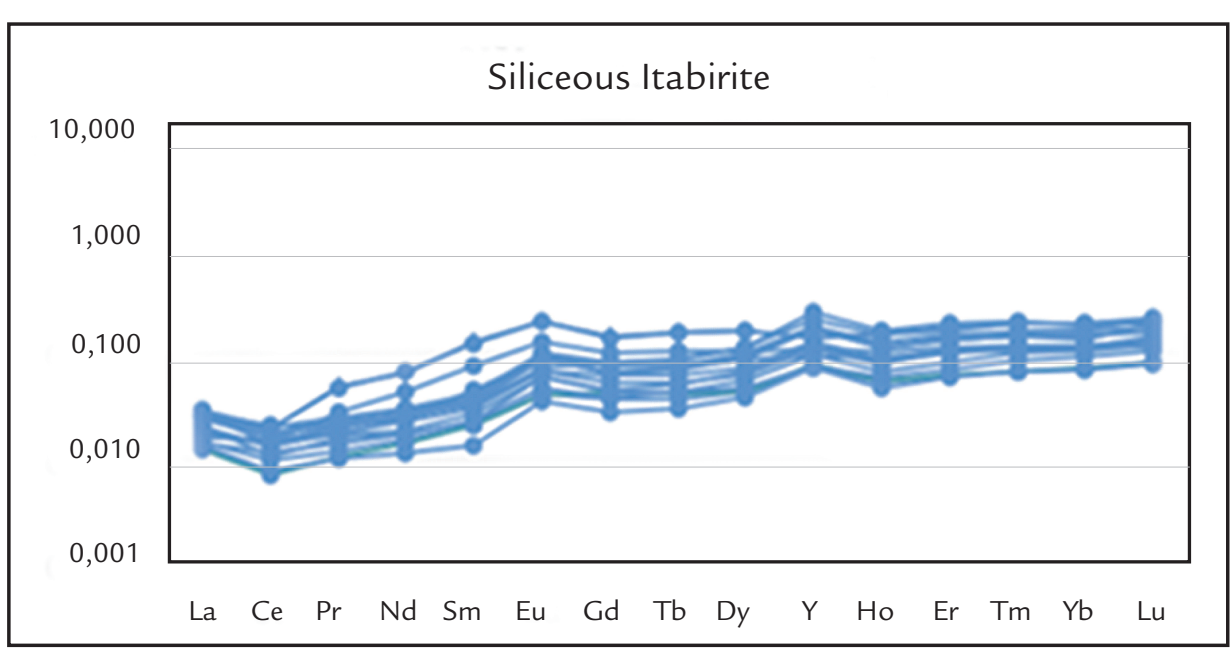


The amphibolitic itabirite, geochemically, has high concentrations of $\mathrm{Fe}_{2} \mathrm{O}_{3}(51.36 \%), \mathrm{Al}_{2} \mathrm{O}_{3}(0.183 \%)$ and $\mathrm{P}_{2} \mathrm{O}_{5}$ $(0.148 \%)$, medium of $\mathrm{SiO}_{2}(42.47 \%), \mathrm{TiO}_{2}$ $(0.002 \%), \mathrm{MgO}(0.100 \%)$ and low $\mathrm{f} \mathrm{FeO}$ $(1.31 \%)$ and $\mathrm{CaO}(0.04 \%)$. Rich in trace elements, such as $\mathrm{Ni}(4.895 \mu \mathrm{g} / \mathrm{g}), \mathrm{Cu}$

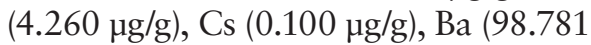
$\mu \mathrm{g} / \mathrm{g})$ and $\mathrm{U}(0.296 \mu \mathrm{g} / \mathrm{g})$, this type of $\mu \mathrm{g} / \mathrm{g}), \mathrm{Sr}(7.397 \mu \mathrm{g} / \mathrm{g}), \mathrm{Zr}(0.870 \mu \mathrm{g} / \mathrm{g}), \mathrm{Hf}$ $(0.017 \mu \mathrm{g} / \mathrm{g}), \mathrm{Th}(0.125 \mu \mathrm{g} / \mathrm{g}), \mathrm{Ga}(0.243$ $\mu \mathrm{g} / \mathrm{g}), \mathrm{Rb}(0.531 \mu \mathrm{g} / \mathrm{g}), \mathrm{Cr}(1.060 \mu \mathrm{g} / \mathrm{g})$, and $\mathrm{Sn}(0.157 \mu \mathrm{g} / \mathrm{g})$.

Containing a total concentration of REE between $8.517 \mu \mathrm{g} / \mathrm{g}$ and $21.132 \mu \mathrm{g} /$, the amphibolitic itabirite has a REE spectrum (Figure 4) characterized by positive Eu anomalies (Planavsky, 2010), positive

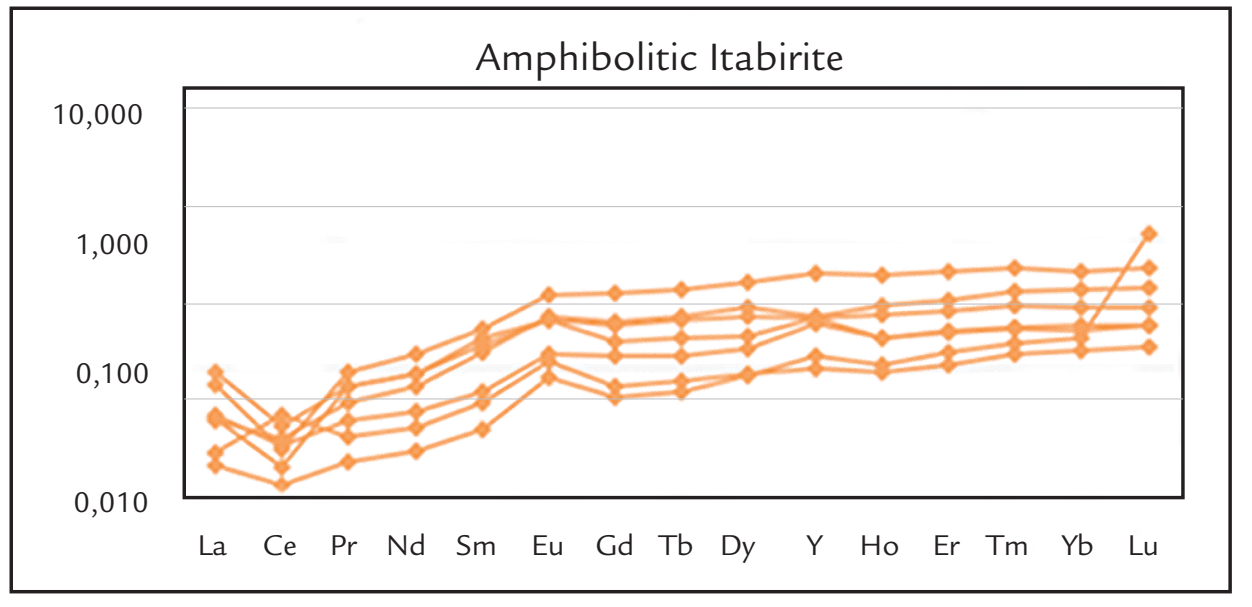

\section{Discussions}

The main general characteristics of the magnetitic itabirite are: low concentrations of the major oxides of Si, P, Fe III and the trace elements of $\mathrm{Ni}, \mathrm{Cu}, \mathrm{Nb}$, In, and $\mathrm{Ba}$, along with the highest concentrations of the oxides of Mn, Ca, Ti, Mg, Fe II and the trace elements of $\mathrm{Cr}, \mathrm{Sc}, \mathrm{Rb}, \mathrm{Sr}, \mathrm{Zr}$, Th, $\mathrm{Hf}$ and $\mathrm{Bi}$, if compared with the siliceous and amphibolitic itabirites. The siliceous itabirite is chemically composed of the lowest concentrations of $\mathrm{Al}, \mathrm{Mn}$ and $\mathrm{Ti}$ oxides and trace elements when compared with the other types of itabirites studied, excluding $\mathrm{Cs}$ and $\mathrm{U}$ that are found in low concentrations. The amphibolitic itabirite is characterized by the highest concentrations of Al, P and Fe III oxides and trace elements as compared to other types of that are found in higher concentrations.

Analyzing the trace elements Sc, Sr, $\mathrm{Zr}$, Hf and Th that are tracers of detrital contamination (Bolhar et al., 2004; Bau \& Möller, 1993, Bau \& Alexander, 2009), the same trend can be seen. The highest concentration of these trace elements is present in the magnetitic type of itabirite. The medium concentrations can be seen in the amphibolitic type and are followed by the ones observed in the siliceous itabirite. It can be inferred that the itabirite type that has the highest detrital contamination amount is the magnetitic being followed by the amphibolitic and finally by the siliceous type.

The average $\mathrm{Y} / \mathrm{Ho}$ ratios observed studied itabirites, excluding $\mathrm{Nb}$, In and $\mathrm{Sn}$
1996) anomalies, enrichment in HREE in relation to the LREE and Y/Ho ratios near 28.82. Analyzing the ratios described by Bau \& Möller (1993), the samples have $(\mathrm{Sm} / \mathrm{Yb})_{\mathrm{SN}}<1$ and $(\mathrm{Eu} / \mathrm{Sm})_{\mathrm{SN}}>1$. Deeply studying the $\mathrm{Ce}$ anomalies as suggested by Planavsky et al. (2010) and Bau \& Dulski (1996), the proposed ratios (Ce/ $\left.\mathrm{Ce}^{*}\right)_{\mathrm{SN}}$ and $\left(\operatorname{Pr} / \mathrm{Pr}^{*}\right)_{\mathrm{SN}}$ indicate that all the samples have truly negative $\mathrm{Ce}$ anomalies.

Figure 4

REE spectrum of the amphibolitic itabirite from Serra Azul, PASS normalized (McLennan, 1989).

in the three different types of itabirites are close ratios $(38.67$ for the magnetitic, 35.59 for the siliceous and 28.82 for the amphibolitic), which are similar to the average ratio (42) determined by Alexander et al. (2008) and (39) for early Archean and early Paleoproterozoic iron formations (Planavsky et al., 2010).

The different types of itabirites of Serra Azul have varied total REE sums. The siliceous type has the lowest sum of these elements, followed by the magnetitic type and, finally, the amphibolitic type, the richer REE lithology. Although there is a difference in the REE sums of the three types of itabirites, when the spectrum of the REE is observed, there are no discrepant differences between them (fig. 5).

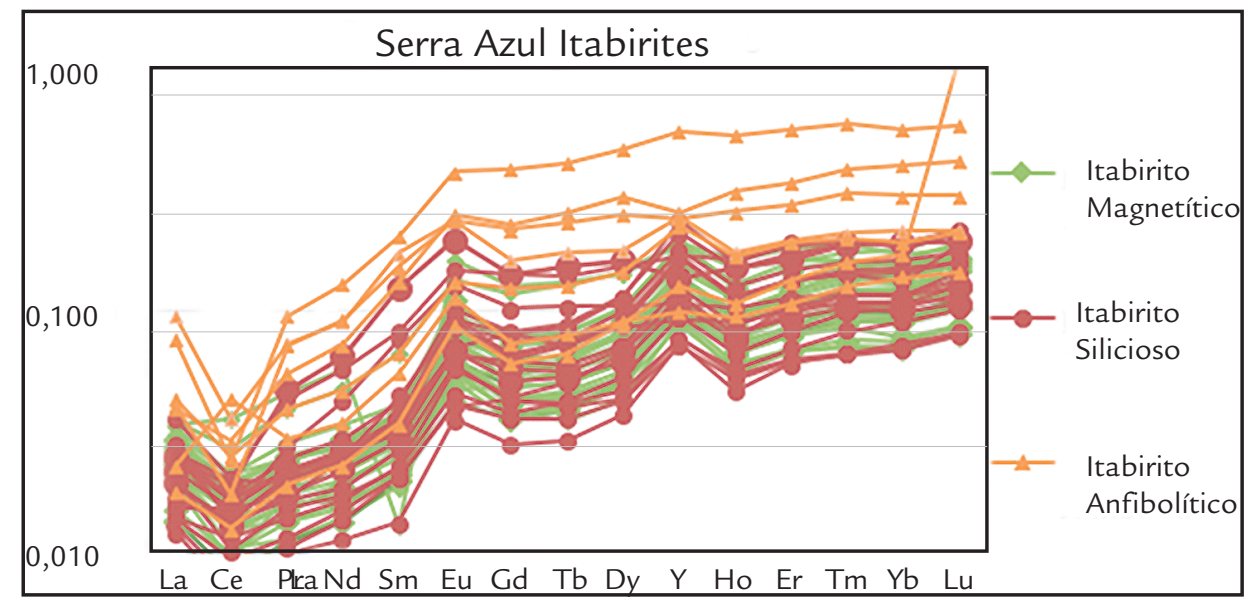

Figure 5

REE spectrum of all the itabirite studied types from Serra Azul, PASS normalized (McLennan, 1989). 
All the three itabirites types studied had as common characteristics: positive $\mathrm{Eu}$ anomalies (Planavsky et al., 2010), enrichment in HREE in relation to the LREE, ratios of $(\mathrm{Sm} / \mathrm{Yb})_{\mathrm{SN}}<1$ and $(\mathrm{Eu} /$ $\mathrm{Sm})_{\mathrm{SN}}>1$. The magnetitic and siliceous

\section{Conclusions}

Geochemically, the magnetitic itabirite is characterized by: the highest concentrations of $\mathrm{MnO}, \mathrm{CaO}, \mathrm{TiO}_{2}$, $\mathrm{MgO}, \mathrm{FeO}$ and trace elements as $\mathrm{Cr}, \mathrm{Sc}$, $\mathrm{Rb}, \mathrm{Sr}, \mathrm{Zr}, \mathrm{Hf}, \mathrm{Th}$ and Bi. The siliceous itabirite is composed of the lowest concentrations of $\mathrm{Al}_{2} \mathrm{O}_{3}, \mathrm{MnO}, \mathrm{TiO}_{2}$ and trace elements, if compared with the other two types of studied itabirites. Characterized by the highest concentrations of $\mathrm{Al}_{2} \mathrm{O}_{3}$, $\mathrm{P}_{2} \mathrm{O}_{5}$ and $\mathrm{Fe}_{2} \mathrm{O}_{3}$, the amphibolitic itabirite contains the highest concentrations of trace elements in the studied samples.

Observing the trace elements described as tracers of detrital contamination (Bolhar et al., 2004; Bau \& Möller,

\section{Acknowledgements}

The authors are grateful to the Mineração Usiminas for letting them collect these samples, study and publishing these results.

\section{References}

type still had the positive $\mathrm{Y}$ anomaly in common, a characteristic that was also present in some samples of the amphibolitic type but there were others that had showed negative $\mathrm{Y}$ anomalies. Positive anomalies of La were character- ized in the magnetitic itabirite and in some samples of the siliceous type that also had samples with true negative $\mathrm{Ce}$ anomalies. The amphibolitic itabirite was characterized as having only true negative $\mathrm{Ce}$ anomalies.

1993, Bau \& Alexander, 2009), it can be inferred that the magnetitic itabirite has the highest contamination and that the siliceous type has the lowest one.

The three itabirite types studied have average $\mathrm{Y} / \mathrm{Ho}$ ratios that are similar to the average proposed for Archean and early Paleoproterozoic iron formations in literature (e.g. Alexander et al., 2008; Planavsky et al., 2010).

Although there are differences in the total sum of REE in the studied itabirite types of Serra Azul, there are no discrepancies in the REE spectrum of each type. The three types had common characteristics in their REE spectrum:

They are grateful to the Fundação de Amparo à Pesquisa do Estado de Minas Gerais (FAPEMIG) and VALE for promote projects RDP-00063-10 i) positive Eu anomalies (Planavsky et al., 2010);

ii) HREE enrichment in relation to the LREE; ratios of $(\mathrm{Sm} / \mathrm{Yb})_{\mathrm{SN}}<1$ and $(\mathrm{Eu} / \mathrm{Sm})_{S \mathrm{~N}}>1$ (Bau \& Möller, 1993). The magnetitic and the siliceous itabirites had positive Y anomalies, a common characteristic that appeared in some amphibolitic samples; on the other hand, the other ones had negative $\mathrm{Y}$ anomalies. Positive anomalies of La were characterized in the magnetitic itabirite and in some samples of the siliceous type that also had samples with true negative $\mathrm{Ce}$ anomalies. The amphibolitic itabirite was characterized as having only true negative Ce anomalies. and RDP-00067-10 and Coordenação de Aperfeiçoamento de Pessoal de Nível Superior (CAPES) for the master scholarship granted.

ALEXANDER, B.W., BAU, M., ANDERSSON, P., DULSKI, P. Continentally-derived solutes in shallow Archean seawater: Rare earth element and $\mathrm{Nd}$ isotope evidence in iron formation from 2.9 Ga Pongola Supergroup, South Africa. Geochimica et Cosmochimica Acta, v. 72, p. 378-394, 2008.

ALKMIM, F. F., MARSHAK, S. Transamazonian orogeny in Southern São Francisco Craton Region, Minas Gerais, Brazil: evidence for Paleoproterozoic Collision and Collapse in Quadrilátero Ferrífero. Precambrian Research, v. 90, p. 29-58, 1998.

ALMEIDA, F. F. M. O Cráton São Francisco. Rev. Bras. Geociências, v. 7, n.4, p. 349-364, 1977.

AMORIM, L. Q., ALKMIM, F. F. New ore types from the Cauê banded iron-formation, Quadrilátero Ferrífero, Minas Gerais, Brazil - Responses to the growing demand. In: IRON ORE CONFERENCE, 2011. Perth, WA. p. 1-14.

BAU, M., ALEXANDER, B. W. Distribution of high field strength elements (Y, Zr, REE, Hf, Ta, Th, U) in adjacent magnetite and chert bands and in reference standards FeR-3 and FeR-4 from the Temagami iron-formation, Canada, and the redox level of the Neoarchean ocean. Precambrian Research, v. 174, p. 337-346, 2009.

BAU, M., DULSKI, P. Distribution of yttrium and rare-earth elements in the Penge and Kuruman iron-formations, Transvaal Supergroup, South Africa. Precambrian Research, v. 79, p. 37-55, 1996.

BAU, M., MÖLLER, P. Rare earth element systematics of the chemically precipitated component in Early Precambrian iron formations and the evolution of the terrestrial atmosphere hydrosphere-lithosphere system. Geochimica et Cosmochimica Acta, v. 57, p. 2239-2249, 1993.

BOLHAR, R., KAMBER, B. S., MOORBATH, S., FEDO, C. M., WHITEHOUSE, M. J. Characterization of early Archean chemical sediments by trace element signatures. Earth and Planetary Science Letters, v. 222, p. 43-60, 2004. 
DISMUKES, G. C., KLIMOV, V. V., BARANOV, S. V., KOZLOV, Y. N., DASGUPTA, J., TYRYSHKIN, A. The origin of atmospheric oxygen on Earth: the innovation of oxygenic photosynthesis. PNAS, v. 98, n. 5, p. 2170-2175, 2001.

LIANG, M. C., HARTMAN, H., KOPP, R. E., KIRSCHVING, J. L. Production of hydrogen peroxide in the atmosphere of a snowball Earth and the origin of oxygenic photosynthesis. PNAS, v. 103, n. 50, p. 18896-18899, 2006.

MCLENNAN, S. M. Rare earth elements in sedimentary rocks: influence of provenance and sedimentary processes. In: LIPIN, B. R., MCKAY, G. A. (ed.). Geochemistry and mineralogy of rare earth elements. Reviews in Mineralogy, v. 21, p. 169-200, 1989.

PIRES, F. R. M. Textural and mineralogical variations during metamorphism of the Proterozoic Itabira Iron Formation in the Quadrilátero Ferrífero, Minas Gerais, Brazil. An. Acad. Brasileira de Ciências, v. 67, n. 1, p. 77-105, 1995.

PLANAVSKY, N., BEKKER, A., ROUXEL, O. J., KAMBER, B., HOFMANN, A., KNUDSEN, A., LYONS, T. W. Rare Earth Element and yttrium compositions of Archean and Paleoproterozoic Fe formations revisited: New perspectives on the significance and mechanisms of deposition. Geochimica et Cosmochimica Acta, v. 74, p. 6387-6405, 2010.

PUFAHL, P. K. Bioelemental sediments. In: JAMES, N. P., DALRYMPLE, R. W. (ed.). Facies Models. 4 ed. Geological Association of Canada, 2010. p. 477-504.

ROSIĖRE, C. A., CHEMALE JR, F. Itabiritos e minérios de ferro de alto teor do Quadrilátero Ferrífero - uma visão geral e discussão. Geonomos, v. 8, n. 2, p. 27 43, 2000.

SAMPAIO, G. M. S. Determinação de elementos-traço em amostras de formações ferríferas por ICP-MS e produção de um material de referência para controle de qualidade. Campinas: UNICAMP, 2012. 56p. (Dissertação de Mestrado).

SPIER, C. A., OLIVEIRA, S. M. B, SIAL, A. N., RIOS, F. J. Geochemistry and genesis of the banded iron formations of the Cauê Formation, Quadrilátero Ferrífero, Minas Gerais, Brazil. Precambrian Research, v. 152, n. 3-4, p. 170-206, 2007.

Received: 13 July 2014 - Accepted: 17 October 2014 